\title{
By-products from the vegetable oil industry as a feasible source for biofuels production and pollution reduction

\author{
R. Piloto-Rodriguez ${ }^{1}$, E. A. Melo ${ }^{1}$, I. Tobio ${ }^{2}$, L. Goyos ${ }^{1}$ and S. Verhelst ${ }^{3}$
}

${ }^{1}$ Center of Studies of Renewable Energies, Instituto Superior Politécnico José A. Echeverría. Calle 114, No. 11901 e/119 y 127, Cujae, Marianao 15, 19390, Cuba, e-mail: rpiloto@ceter.cujae.edu.cu

\author{
${ }^{2}$ Facultad de Ingeniería Química, Instituto Superior Politécnico José A. Echeverría. Calle 114, No. 11901 e/119 y 127 , \\ Cujae, Marianao 15, 19390, Cuba \\ ${ }^{3}$ Department of Flow, Heat and Combustion Mechanics. Ghent University, Belgium
}

\begin{abstract}
Biodiesel produced from by-products and waste materials can be an economical way for reducing the traditional oil consumption and environmental problems. The by-products from the refining vegetable oil industry such as soapstock, acid oil and fatty acid distillates are suitable for producing biodiesel. The present work is an approach to the use of these by-products to obtain biodiesel covering the traditional and most widely used acid/base catalysis. The advantages and drawbacks of the different methods are mentioned and analysed. The synthesis and use of by-products from the vegetable oil refining industry are covered in this work.
\end{abstract}

\section{Key words}

Biodiesel, soapstock, acid oil, fatty acid distillate

\section{Introduction}

Biodiesel is a well-known renewable commodity. It is composed of fatty acid methyl esters (FAMEs) [1-3]. The production cost for biodiesel is still higher compared to diesel fuel but this can be expected to decrease in the future. More than $75 \%$ of the production costs of biodiesel are due to the costs of the raw materials.

Some by-products of low commercial value are obtained from these refining processes. Important amounts of byproducts such as soapstocks (SS), deodorizer fatty acid distillates (FAD) and acid oil (AO) are produced from the oil refining processes. These by-products are harmful to the environment if they cannot be used for any beneficial or industrial activity. The use of by-products for biodiesel production is a very good alternative for cost reduction of biofuels production and to solve related environmental problems.

The scope of this paper is to demonstrate the feasibility of the biodiesel obtaining from three less used by-products of the refining oil industry (soapstock, acid oil and fatty acid distillate) and the industrial residuals reduction associated to this treatment proposal. An approach to their use in internal combustion engines is also included.

\section{Vegetable oil refining}

Chemical refining is the most widely used technique to purify the vegetable oils since it successfully decreases the level of free fatty acids (FFAs), phospholipids, waxes, aldehydes, ketones among other components, but also the physical refining is widely used.

Soapstock emerges from the refining process when oil is treated with a dilute alkali solution separating the FFAs as is more simplified for the removing of FFAs than the chemical process and also reduces the amount of oil loss, but cannot avoid the production of a by-product in important amounts.

\section{Use of by-products of the refining oil industry to} produce biodiesel

Three main by-products from the refining oil industry are obtained, as is observed in Fig.1. Soapstocks, acid oil and fatty acid distillate represents low value by-products but according to the composition, they are suitable for the production of biodiesel, adding value to them and a higher efficiency to the vegetable oil refineries.

Soapstock emerges from the refining process when oil is treated with a dilute alkali solution separating the FFAs as soaps. This wet lipid mixture is separated from the crude oil by centrifugation. It is generated at a rate of about $6 \%$ of the input of oil entering the refining operation and its cost represents $1 / 10$ of the refined oil cost. Soapstock is quite alkaline, with $\mathrm{pH}$ values between 10-11. This residual is also referred to as residual oleins [5] and has poor commercial value; therefore its use to produce biofuels generates a second generation biofuel.

Several methods proposed for the synthesis of biodiesel from the analysed by-products using the homogeneous acid/base catalysis are published. Most of them used washing and purification processes.

In the field of patents several are registered. Some of them cover methods for biodiesel production from soapstock, recovering of products from soapstock, obtaining of biodiesel from soapstock using enzymatic esterification or acidulation.

One of the potential raw materials for biodiesel production is the Fatty Acid Distillate (FAD) that contains high amounts of FFAs. It is also a by-product obtained through the final deodorization stage of the refining process [6]. 
The unsaponifiable materials of FAD have been considered a potential source of highly valuable phytochemicals.

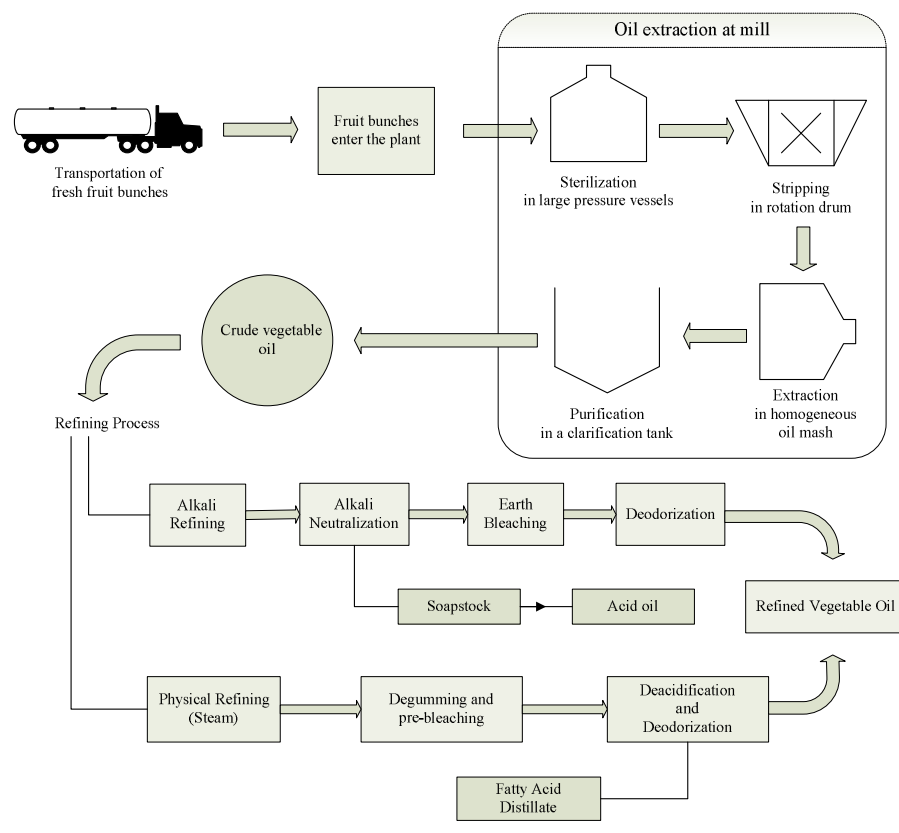

Fig.1 Full processing flow chart for a general vegetable oil refining process

Biodiesel can be obtained from the acid oil that results from the soapstock treatment with sulphuric acid. Its use for biodiesel production can also improve the economic feasibility of the biodiesel process. The acid oil (AO) also known as high-acid oil [7] consists of a long chain FFA mixture along with small amounts of mineral acids, glyceride, phospholipids and sterols and is contaminated with fatty matter. Acidulation of soapstock is one of the least desirable processes in an integrated facility because it is difficult to perform it effectively and its cost has no significant return [8]. The obtaining of biodiesel from AO is reported and under regular conditions can produce biodiesel or a biofuel but the influence of their use in internal combustion engines is still under studies.

\section{Heterogeneous and enzymatic catalysts}

The development of heterogeneous catalysts has been a relatively recent area of research in the synthesis of biodiesel. Their use has a great potential not only technologically but economically $[9,10]$. The aim for the development of heterogeneous catalysts is related to the homogeneous catalysts drawbacks: washing of biodiesel with water to remove the catalyst present, which results in wastewater and loss of biodiesel as a result of water washing.

Next to the heterogeneous catalysis based synthesis, the use of enzymes has also been reported. Biodiesel production using enzyme catalysts is a more environmentally friendly process and reaches adequate or even higher yields than the previously analysed processes [10-12], but these processes involving enzymes are costly.
Table 1. FFA and glyceride content in by-products from different feedstocks

\begin{tabular}{|c|c|c|c|}
\hline Feedstock & Feedstock & $\begin{array}{c}\text { FFA } \\
(\text { wt } \%)\end{array}$ & $\begin{array}{c}\text { Glycerides } \\
\text { (wt \%) }\end{array}$ \\
\hline \multirow{8}{*}{$\begin{array}{c}\text { Fatty acid } \\
\text { distillate }\end{array}$} & Cotton & 85.0 & Not specified \\
\hline & Palm & 93.0 & Not specified \\
\hline & Hazelnut & $45-50$ & Not specified \\
\hline & Palm & $70-80$ & $20-30$ \\
\hline & Soybean & 40.2 & Not specified \\
\hline & Soybean & 45.4 & 23.3 \\
\hline & Soybean & 30.1 & 13.0 \\
\hline & Rapeseed & 48.8 & 32.9 \\
\hline \multirow[t]{7}{*}{ Soapstock } & Soybean & 51.6 & Not specified \\
\hline & Sunflower & 70.0 & 25.0 \\
\hline & Soybean & 10.0 & 13.9 \\
\hline & Cotton & 85.3 & Not specified \\
\hline & Sunflower & 56.0 & Not specified \\
\hline & Soybean & 35.0 & Not specified \\
\hline & Cotton & 60.0 & Not specified \\
\hline \multirow[t]{5}{*}{ Acid oil } & Palm & 88.1 & Not specified \\
\hline & Soybean & 59.3 & 33.4 \\
\hline & Cotton & 86.0 & Not specified \\
\hline & Corn & 46.0 & Not specified \\
\hline & Rapeseed & 77.9 & 10.8 \\
\hline
\end{tabular}

Using enzymes, conversion efficiency between 70-90\% for the transesterification reaction can be obtained. Using lipase, $63 \%$ of esterification conversion is reported [13] with an overall efficiency of $81 \%$.

\section{Use in Internal Combustion Engines}

A direct injection single cylinder Petter engine TD111 with a compression ratio $17: 1$ and fuel injection timing 24-33 ${ }^{\circ}$ (before top dead center) was used to test blends of biodiesel obtained from cotton oil soapstock and diesel fuel increasing the percent of biodiesel in the blend up to $60 \%$ [14].

A Ford XLD four cylinder, four stroke, water cooled, 21.5:1 compression ratio, turbocharged, indirect injection diesel engine was used to test blends of biodiesel-diesel fuel [15]. The volume percent was up to $25 \%$ of biodiesel in the blends. Although the heating value of the biodiesel is lower than diesel fuel, they found for biodiesel blends a slightly higher torque and power output at full load and partial loads. At partial loads, it was found that the blend did not cause significant changes in the $\mathrm{CO}$ and $\mathrm{CO}_{2}$ emissions.

Haas et al. [13] conducted tests in a heavy-duty truck engine. It was a six-cylinder four-stroke, direct injection, turbocharged, intercooled and nominally rated at $257 \mathrm{~kW}$ at $1800 \mathrm{rpm}$. As fuel $100 \%$ soapstock based biodiesel, commercial biodiesel prepared from soybean and a reference diesel fuel were tested. For HC emissions they 
Table 2. Conditions and yields in esterification of the by-products using the homogeneous acid/base catalysis

\begin{tabular}{|c|c|c|c|c|c|c|c|}
\hline Feedstock & Catalyst & $\begin{array}{l}\text { Temp. } \\
\left({ }^{\circ} \mathrm{C}\right)\end{array}$ & MeOH/oil & $\begin{array}{l}\text { Catalyst } \\
\text { amount }\end{array}$ & $\begin{array}{l}\text { Reaction } \\
\text { time }(h)\end{array}$ & Yield (\%) & Comments \\
\hline \multirow[t]{2}{*}{ Palm FAD } & $\mathrm{H}_{2} \mathrm{SO}_{4}$ & 75 & $\begin{array}{c}8.8: 1 \\
\mathrm{~mol} / \mathrm{mol}\end{array}$ & 1.83 wt $\%$ & 1 & 99.5 & $\begin{array}{c}\text { Reducing } \\
\text { glycerides by } \\
\text { alkaline washing }\end{array}$ \\
\hline & $\begin{array}{c}\text { Acid: } \mathrm{H}_{2} \mathrm{SO}_{4} \\
\text { Base: } \mathrm{KOH}\end{array}$ & $\begin{array}{l}\text { Acid: } 60 \\
\text { Base: } 60\end{array}$ & $\begin{array}{c}\text { Acid: } \\
\text { 20mol } / \mathrm{mol} \\
\text { Base: } \\
8 \mathrm{~mol} / \mathrm{mol}\end{array}$ & $\begin{array}{c}\text { Acid: } 1 \mathrm{v} / \mathrm{wt} \\
\% \\
\text { Base: } 0.6 \mathrm{wt} \\
\%\end{array}$ & $\begin{array}{c}\text { Acid: } 2 \\
\text { Base: } 40 \\
\text { min }\end{array}$ & 98.5 & $\begin{array}{l}\text { Intermediate } \\
\text { neutralization }\end{array}$ \\
\hline Cotton SS & $\mathrm{H}_{2} \mathrm{SO}_{4}$ & 75 & $\begin{array}{l}20 \mathrm{wt} \% \text { of } \\
\text { the SS mass }\end{array}$ & $\begin{array}{l}5 \% \text { of the } \\
\text { SS mass }\end{array}$ & $11 / 2$ & $\begin{array}{c}\text { Not } \\
\text { specified }\end{array}$ & $\begin{array}{l}\text { Pre-heating to } \\
100{ }^{\circ} \mathrm{C} \\
\text { washing with } \\
\mathrm{NaHCO}_{3}\end{array}$ \\
\hline $\begin{array}{l}\text { Sunflower } \\
\text { SS }\end{array}$ & \multirow{2}{*}{$\begin{array}{l}\text { Acid: } \mathrm{H}_{2} \mathrm{SO}_{4} \\
\text { Base: } \mathrm{NaOH} \\
\text { Base: } \mathrm{NaOH} \\
\text { Acid: } \mathrm{H}_{2} \mathrm{SO}_{4}\end{array}$} & $\begin{array}{l}\text { Acid: } 60 \\
\text { Base: } 60\end{array}$ & $\begin{array}{c}\text { Acid: } \\
\text { 6mol/mol SS } \\
\text { Base: } \\
\text { 6-20mol/mol } \\
\text { TG }\end{array}$ & $\begin{array}{c}\text { Acid: } 5 \mathrm{wt} \\
\% \\
\text { Base: } 1 \mathrm{wt} \\
\%\end{array}$ & $\begin{array}{l}\text { Acid: } 2 \\
\text { Base: } 2\end{array}$ & 87.0 & $\begin{array}{c}\text { Intermediate } \\
\text { neutralizationwa } \\
\text { shing with } \\
\mathrm{MeOH} / \mathrm{H}_{2} \mathrm{O}\end{array}$ \\
\hline Soybean SS & & $\begin{array}{l}\text { Acid: } 85 \\
\text { Base: } 65\end{array}$ & $\begin{array}{c}\text { Acid: } \\
\text { 5mol/mol SS } \\
\text { Base: } \\
\text { 6mol } / \mathrm{mol} \mathrm{SS} \\
\end{array}$ & $\begin{array}{c}\text { Acid: } 3 \mathrm{wt} \\
\% \\
\text { Base: } 1 \mathrm{wt} \\
\% \\
\end{array}$ & $\begin{array}{l}\text { Acid: } 5 \\
\text { Base: } 1\end{array}$ & $\begin{array}{l}\text { Acid: } 90.0 \\
\text { Base: } 94.0\end{array}$ & Three steps \\
\hline \multirow[t]{2}{*}{$\begin{array}{c}\text { Soybean } \\
\text { AO }\end{array}$} & \multirow[t]{2}{*}{$\mathrm{H}_{2} \mathrm{SO}_{4}$} & $\begin{array}{l}80(1 h) \\
95(4 h)\end{array}$ & $\begin{array}{c}2: 1 \\
\mathrm{~mol} / \mathrm{mol} \mathrm{AO}\end{array}$ & $\begin{array}{l}\text { Not clearly } \\
\text { specified }\end{array}$ & 3 & 90.0 & $\begin{array}{l}\text { Pressurized } \\
\left(4 \mathrm{kgf} / \mathrm{cm}^{2}\right) \\
\text { Distillation } \\
\end{array}$ \\
\hline & & $\begin{array}{c}100 \\
35\end{array}$ & $\begin{array}{l}15: 1 \\
30: 1\end{array}$ & $\begin{array}{c}15: 1 \\
\mathrm{~mol} / \mathrm{mol} \\
5: 1 \mathrm{~mol} / \mathrm{mol}\end{array}$ & $\begin{array}{c}2-4 \\
2\end{array}$ & $\begin{array}{l}- \\
99\end{array}$ & $\begin{array}{l}\text { unesterified FFA } \\
\text { residual is } \\
\text { removed by } \\
\text { washing }\end{array}$ \\
\hline
\end{tabular}

reported between $25-50 \%$ reductions compared to diesel fuel. They found an increase in the brake specific fuel consumption around $18 \%$, related to the lower energy density of the biodiesel.

Jonas et al. [16] tested fatty acid distillates in a medium speed diesel engine. The by-product was heated to $110{ }^{\circ} \mathrm{C}$ in order to decrease the viscosity to $8 \mathrm{mPas}$. During the investigation, dark deposits were detected on the piston crown, the rings, the combustion chamber and the injector.

A lack of papers about the use of biodiesel obtained from these by-products was found, meaning that this is a widely open field for research. Most research is focused on obtaining better yields of biodiesel, more efficient chemical processes and cost reductions.
According to the approach and the scope of this paper, a number of tables were omitted. All the information related to a more complete approach to the use of industrial residuals for biofuels or biodiesel production for their use in internal combustion engines can be consulted in an accepted paper soon published in the Brazilian Journal of Chemical Engineering entitled: Conversion of byproducts from the vegetable oil industry into biodiesel and its use in Internal Combustion Engines: A Review. 
Table 3 Reaction conditions and yields for various methods used in transesterification of the by-products using heterogeneous catalysis

\begin{tabular}{|c|c|c|c|c|c|c|c|}
\hline Feedstock & Catalyst & $\begin{array}{l}\text { Temp. } \\
\left({ }^{\circ} \mathrm{C}\right)\end{array}$ & MeOH/oil & $\begin{array}{l}\text { Catalyst } \\
\text { amount }\end{array}$ & $\begin{array}{l}\text { Reaction } \\
\text { time }(h)\end{array}$ & Yield (\%) & Comments \\
\hline $\begin{array}{c}\text { Soybean } \\
\text { AO }\end{array}$ & LCC & 70 & $\begin{array}{c}9: 1 \\
\mathrm{~mol} / \mathrm{mol}\end{array}$ & $\begin{array}{c}7 \text { wt } \% \text { of } \\
\mathrm{AO}\end{array}$ & 5 & 97.2 & - \\
\hline $\begin{array}{l}\text { Cotton \& } \\
\text { Corn AO }\end{array}$ & $\begin{array}{c}\mathrm{SO}_{4}^{2-} / \mathrm{TiO}_{2^{-}} \\
\mathrm{SiO}_{2}\end{array}$ & 200 & $\begin{array}{c}9 \mathrm{~mol} / \mathrm{mol} \\
\mathrm{SS}\end{array}$ & $3 \mathrm{wt} \%$ & 6 & 94.0 & $\begin{array}{c}\text { Continuous } \\
\text { process }\end{array}$ \\
\hline Palm FAD & $\begin{array}{c}\mathrm{H}_{3} \mathrm{PW}_{12} \mathrm{O}_{40} / \mathrm{Si} \\
\mathrm{O}_{2} \\
\mathrm{Cs}_{1.5} \mathrm{H}_{1.5} \mathrm{PW}_{12} \\
\mathrm{O}_{40} / \mathrm{SiO}_{2}\end{array}$ & 85 & $12 \mathrm{~mol} / \mathrm{mol}$ & $15 \mathrm{wt} \%$ & 15 & 96.7 & $\begin{array}{c}\text { Complex } \\
\text { catalyst } \\
\text { preparation }\end{array}$ \\
\hline $\begin{array}{l}\text { AO source } \\
\text { not } \\
\text { specified }\end{array}$ & $\begin{array}{c}\text { Acid: } \mathrm{SO}_{4}{ }^{2-} \\
/ \mathrm{ZrO}_{2}^{-} / \mathrm{La}^{3+} \\
\text { Base: sodium } \\
\text { methoxide }\end{array}$ & $\begin{array}{l}\text { Acid: } 60 \\
\text { Base: } 55\end{array}$ & $\begin{array}{c}\text { Acid: } \\
\text { 15mol } / \mathrm{mol} \\
\text { Base: } \\
5 \mathrm{~mol} / \mathrm{mol} \\
\end{array}$ & $\begin{array}{c}\text { Acid: } 5 \text { wt } \% \\
\text { Base: } \\
0.6 \text { wt } \% \\
\end{array}$ & $\begin{array}{c}\text { Acid: } 4 \\
\text { Base: } 0.5\end{array}$ & $\begin{array}{l}\text { Acid: } 98.0 \\
\text { Base: } 97.2\end{array}$ & $\begin{array}{l}\text { Previous } \\
\text { distillation }\end{array}$ \\
\hline $\begin{array}{c}\text { AO source } \\
\text { not } \\
\text { specified }\end{array}$ & $\mathrm{WO}_{3} / \mathrm{ZrO}_{2}$ & 150 & $9 \mathrm{~mol} / \mathrm{mol}$ & $20 \mathrm{wt} \%$ & $\begin{array}{l}0.4 \mathrm{~g} / \mathrm{mL} \\
\quad \text { (oil) }\end{array}$ & 96.0 & - \\
\hline $\begin{array}{l}\text { Rapeseed } \\
\text { FAD }\end{array}$ & - & 60 & $\begin{array}{c}\text { 6-15 } \\
\mathrm{mol} / \mathrm{mol}\end{array}$ & - & 4 & $93-97$ & $\begin{array}{c}\text { cation } \\
\text { exchange } \\
\text { resins D002 } \\
\text { and } 002 \mathrm{CR} \text {, } \\
\text { flow rate } 1 \\
\mathrm{~mL} / \mathrm{min} \\
\end{array}$ \\
\hline $\begin{array}{c}\text { Rapeseed } \\
\text { FAD }\end{array}$ & $\mathrm{H}_{2} \mathrm{SO}_{4}$ & 60 & $\begin{array}{c}12: 1 \\
\mathrm{~mol} / \mathrm{mol}\end{array}$ & $5 \mathrm{wt} \%$ & 4 & 96.8 & - \\
\hline
\end{tabular}

\section{Conclusions}

The feasibility of the use of by-products from the refining oil industry to produce biodiesel across the amount of papers published is clear. There currently is a trend to change from the traditional acid/base catalyst to heterogeneous or enzymatic catalysts in order to eliminate the traditional drawbacks. The so called low commercial value by-products are really suitable to extraction or isolation of several industrially useful compounds in a wide range of applications. A huge disparity in the amount of papers published in this topic is found comparing the synthesis of biodiesel and the performance of the biodiesel produced in diesel engines.

\section{Acknowledgments}

The authors wish to express their thanks to the Flemish Interuniversity Council's (VLIR) University Development Cooperation, funding an Own Initiatives Program, with whose support much of this work was performed under a project entitled "Knowledge cell on biofuels (from nonedible crops and waste products) for use in internal combustion engines".

\section{References}

1. Lois, E., Letter to the editor. Fuel, 2007. 87: p. 12121213.

2. Demirbas, A., Progress and recent trends in biodiesel fuels. Energy Conversion \& Management, 2009. 50: p. 14-34.

3. Lapuerta, M., O. Armas, and J. Rodriguez-Fernandez, Effect of biodiesel fuels on diesel engine emissions. Progress in Energy and Combustion Science, 2008. 34: p. 198-223.

4. Haslenda, H. and M.Z. Jamaludin, Industry to Industry By-products Exchange Network towards zero waste in 
palm oil refining processes. Resources, Conservation and Recycling, 2011. 55: p. 713-718.

5. Pereda, J., F. Barriga, and P. Alvarez, Aprovechamiento de las oleinas residuales procedentes del proceso de refinado de los aceites vegetales comestibles, para la fabricación de biodiesel. Grasas y Aceites, 2003. 54(2): p. 130-137.

6. Yang, H., et al., Recovery of phytosterols from waste residue of soybean oil deodorizer distillate. Bioresource Technology, 2010. 101: p. 1471-1476.

7. Cherng-Yuan, L. and L. Yi-Wei, Fuel Characteristics of Biodiesel Produced from a High-Acid Oil from Soybean Soapstock by Supercritical-Methanol Transesterification. Energies, 2012. 5: p. 2370-2380.

8. Zhong-Ming, W., et al., Novel biodiesel production technology from soybean soapstock. Korean J. Chem. Eng., 2007. 24(6): p. 1027-1030.

9. Marchetti, J.M., A summary of the available technologies for biodiesel production based on a comparison of different feedstock's properties. Process Safety and Environment Protection, 2012. 90: p. 157-163.

10. Joon, C.J., et al., Biodiesel production from jatropha oil by catalytic and non-catalytic approaches: An overview. Bioresource Technology, 2011. 102: p. 452-460.

11. Rivera, I., G. Villanueva, and G. Sandoval, Producción de biodiesel a partir de residuos grasos animales por vía enzimática. Grasas y Aceites, 2009. 60(5): p. 468-474.

12. Yujaroen, D., et al., Esterification of palm fatty acid distillate (PFAD) in supercritical methanol: Effect of hydrolysis on reaction reactivity. Fuel, 2009. 88: p. 20112016.

13. Haas, M.J., Improving the economics of biodiesel production through the use of low value lipids as feedstocks: vegetable oil soapstock. Fuel Processing Technology, 2005. 86: p. 1087-1096.

14. Keskin, A., et al., Using of cotton oil soapstock biodiesel-diesel fuel blends as an alternative diesel fuel. Renewable Energy, 2008. 33: p. 553-557.

15. Usta, N., et al., Combustion of biodiesel fuel produced from hazelnut soapstock/waste sunflower oil mixture in a Diesel engine. Energy Conversion \& Management, 2005. 46: p. 741-755.

16. Galle, J., et al., Failure of fuel injectors in a medium speed diesel engine operating on bio-oil. Biomass \& Bioenergy DOI:10.1016/j.biombioe.2012.01.041, 2012. 